\title{
Curious case of a toddler with discrepant limb lengths and gangrene: a rare vascular malformation
}

\author{
Himanshi Chaudhary (D) ,' Archana Krishnappa, ${ }^{2}$ Ankur Kumar Jindal, ${ }^{1}$ \\ Rajesh Vijayvergiya ${ }^{3}$
}

'Pediatrics, Post Graduate Institute of Medical Education and Research, Chandigarh, India ${ }^{2}$ Advanced Pediatrics Center, Post Graduate Institute of Medical Education and Research, Chandigarh, India ${ }^{3}$ Advanced Cardiac Center, Post Graduate Institute of Medical Education and Research, Chandigarh, India

\section{Correspondence to} Dr Ankur Kumar Jindal; ankurjindal11@gmail.com

Accepted 21 May 2020 (c) BMJ Publishing Group Limited 2020. No commercial re-use. See rights and permissions. Published by BMJ.

To cite: Chaudhary $\mathrm{H}_{\text {, }}$ Krishnappa A, Jindal AK, et al. BMJ Case Rep 2020:13:e235800 doi:10.1136/bcr-2020235800

\section{DESCRIPTION}

A 14-month-old boy was referred to us for the evaluation of differential growth of lower limbs noted since birth and dusky discolouration of the left leg. The mother noted that the left lower limb was thinner, shorter and weaker than the right lower limb since birth. He experienced an uneventful antenatal, birth and postnatal period. A slight delay in the motor milestones was noted and he preferentially used his right lower limb for weight bearing. He had developed a dusky discolouration over the medial aspect of the left leg (following a trivial trauma) for 2 weeks. He had patchy areas of gangrene in left leg (figure 1A) with absent popliteal, dorsalis pedis and posterior tibial artery pulsations in the left lower limb. There was no hypertension and other peripheral pulses were well palpable. Systemic examination was unremarkable. There was no evidence of facial dysmorphisms, joint hypermobility or laxity of the skin. Haematological, biochemistry and inflammatory parameters were normal. CT angiogram (CTA) revealed multiple congenital ectatic and fusiform arterial aneurysms and tortuosity of left common iliac, external iliac and proximal one-third of superficial femoral artery with persistent left sciatic artery and multiple thrombi in deep and superficial veins and arteries of left lower limb (figure 1B). Thoracic and abdominal aorta were normal in the CTA and magnetic resonance angiography of brain showed normal vessel architecture. Echocardiography showed normal morphology of the proximal aorta and coronary arteries. He was initiated on low molecular weight heparin, aspirin and intravenous antimicrobials. In view of large arterial segment involvement, young age of the patient and worsening infection, an above knee amputation of the left lower limb was performed at 2 years of age. Postoperatively, the surgical site showed good healing and he is doing well at 18 months of follow-up.

Arterial malformations in children are uncommon and are often ascribed to inherited connective tissue abnormalities or inflammatory vasculitis. There are two types of vascular malformations: high-flow malformations (involving arteries, fistulae and arteriovenous malformations) and low-flow malformations (involving capillaries, veins and lymphatics). Connective tissue disorders such as Ehlers-Danlos syndrome, Marfan syndrome, arterial tortuosity syndrome and Loeys Dietz syndrome are commonly associated with vascular abnormalities involving the aorta and peripheral arteries. ${ }^{1}$ Arterial tortuosity syndrome is a rare autosomal recessive connective tissue disorder that is associated with mutation in SLC2A10 gene. The affected children have a distinctive phenotype of long narrow face, keratoconus, blepharophimosis, micrognathia, arachnodactyly, diaphragmatic hernia, hypotonia and joint laxity. Aorta and middle-sized arteries may be tortuous, dilated, aneurysmal or stenosed. Large veins can also be involved. ${ }^{2}$ However, these diseases usually have widespread vessel involvement and associated cutaneous and systemic abnormalities. Inflammatory vasculitis like Takayasu arteritis, Kawasaki disease or polyarteritis nodosa can also present with vessel wall abnormalities and peripheral limb ischemia. ${ }^{3}$ Our patient had a thinner and shorter left limb (in comparison to right lower limb) since birth. These points towards chronic ischemia suggesting that the vascular abnormality developed early in the course of fetal development. There were no systemic symptoms suggestive of vasculitis and no morphological or phenotypical characteristics suggesting any inherited connective tissue abnormality. The inflammatory parameters were not elevated, which was also against a possibility of vasculitis. The CTA was also suggestive of a high-flow vascular malformation involving both arteries and veins of the left lower limb. The presence of persistent sciatic artery, a rare embryonic remnant of the lower limb artery that normally regresses in early embryonic development, further supports a diagnosis of congenital vascular malformation. ${ }^{4}$ Treatment options for congenital vascular malformations involve a multidisciplinary approach involving vascular surgeons, plastic surgeons, radiologists, orthopaedic surgeons, cardiologists and paediatricians. ${ }^{5}$ The distinction

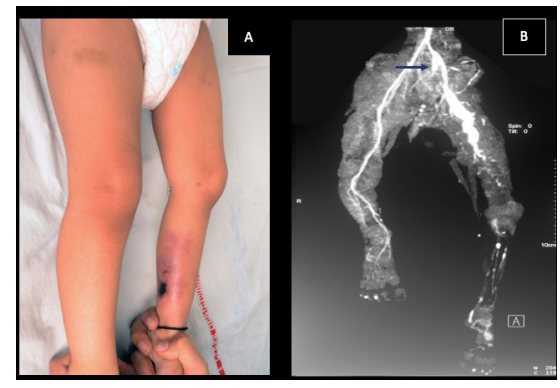

Figure 1 (A) Thinning of the left leg of the patient in comparison to right leg and cellulitis and gangrene over distal part of left leg. (B) CT angiogram of lower limbs showing multiple congenital ectatic and fusiform arterial aneurysms and tortuosity of left common iliac, external iliac and proximal one-third of superficial femoral artery with persistent left sciatic artery (arrow). 
between the two types of malformations is important to decide the therapy (sclerotherapy for low-flow malformations and embolisation for high-flow malformations). Our patient had a high-flow arteriovenous malformation. Early embolisation and surgical revascularisation procedures may have provided a limb salvage therapy in our patient.

\section{Learning points}

- We report a rare vascular cause of limb hypoplasia.

- One must think beyond inflammatory vasculitis and procoagulant states in patients presenting with skin infarcts especially when it is limited to a single limb.

- Limb hypoplasia detected at birth warrants an early evaluation for any vascular abnormality and early revascularisation procedures may help salvage the affected limb.

Acknowledgements Dr Anupam Lal, Professor, Department of Radiodiagnosis, Postgraduate Institute of Medical Education and Research, Chandigarh, India for carrying out the radiological investigation for this patient.

Contributors HC, AK and RV: patient management, conception and design, draft of the manuscript, final approval of the version published, agreement to be accountable for the article and to ensure that all questions regarding the accuracy or integrity of the article are investigated and resolved. AKJ: patient management, conception and design, draft of manuscript, final approval of the version published, revising it critically for important intellectual content, agreement to be accountable for the article and to ensure that all questions regarding the accuracy or integrity of the article are investigated and resolved. He will act as guarantor for the paper.

Funding The authors have not declared a specific grant for this research from any funding agency in the public, commercial or not-for-profit sectors.

Competing interests None declared.

Patient consent for publication Parental/guardian consent obtained.

Provenance and peer review Not commissioned; externally peer reviewed.

\section{ORCID iD}

Himanshi Chaudhary http://orcid.org/0000-0001-6350-6920

\section{REFERENCES}

1 Lopez-Gutierrez JC, Rodríguez LC, Bret Zurita M, et al. Multiple congenital ectatic and fusiform arterial aneurysms associated with lower limb hypoplasia. J Vasc Surg 2012;56:496-9.

2 Beyens A, Albuisson J, Boel A, et al. Arterial tortuosity syndrome: 40 new families and literature review. Genet Med 2018;20:1236-45.

3 Weiss PF, vasculitis P. Pediatric vasculitis. Pediatr Clin North Am 2012;59:407-23.

4 Shaffer W, Maher M, Maristany M, et al. Persistent sciatic artery: a favorable anatomic variant in a setting of trauma. Ochsner J 2017;17:189-94.

5 Akita S, Houbara S, Hirano A. Management of vascular malformations. Plast Reconstr Surg Glob Open 2014;2:e128.

Copyright 2020 BMJ Publishing Group. All rights reserved. For permission to reuse any of this content visit https://www.bmj.com/company/products-services/rights-and-licensing/permissions/

BMJ Case Report Fellows may re-use this article for personal use and teaching without any further permission.

Become a Fellow of BMJ Case Reports today and you can:

- Submit as many cases as you like

- Enjoy fast sympathetic peer review and rapid publication of accepted articles

- Access all the published articles

Re-use any of the published material for personal use and teaching without further permission

\section{Customer Service}

If you have any further queries about your subscription, please contact our customer services team on +44 (0) 2071111105 or via email at support@bmj.com.

Visit casereports.bmj.com for more articles like this and to become a Fellow 